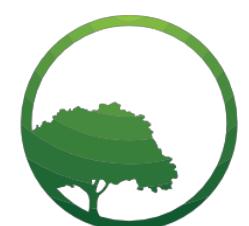

Business \& Social Science IJRBS

\section{Research in Business and Social Science}

IJRBS Vol 7 No 3, ISSN: 2147-4478

Contents available at www.ssbfnet.com/ojs

\title{
E-commerce Taxation and Fiscal Policy Perspective: The Case of Indonesia
}

\section{Sigit Setiawan}

Senior Researcher at Fiscal Policy Agency, Ministry of Finance Indonesia

\begin{abstract}
The Indonesian government is now seriously exploring in depth the proposed tax imposition for ecommerce. In this context, this paper will discuss the following issues: the first, if Indonesian government should impose the tax on e-commerce; the second, how much the potential tax revenue from ecommerce is; and the third, how Indonesian fiscal policy perspective views e-commerce taxation. The study in this paper adopts a descriptive analytical research method. The study concludes several points. Indonesia should tax its e-commerce. The total potential tax revenue on e-commerce from VAT and income tax in 2018 ranges from almost Rp11.75 trillion to Rp16.64 trillion, with VAT dominates the contribution up to more than $90 \%$ of the total tax revenue. By not levying the tax in the year means Indonesian government will lose a partial or the most of tax revenue. The revenue loss is potentially getting bigger in the coming years if the government still fails to collect the tax. E-commerce taxation should not be strictly enforced in the beginning, yet more is emphasized on socialization and education actions. It is also intended to help the online platform to be compliant. Tax policy in Indonesian e-commerce can be potentially used for the purpose of regulating the economy, such as to control excessive online import purchasing.
\end{abstract}

Key words: E-Commerce, Taxation, Fiscal Policy, Tax Revenue

JEL classification: H25, H30, M21

Submitted: 11.09.2018 - Accepted: 15.11.2018

\section{Introduction}

The development of technology has penetrated into all aspects of human life and many people make use of it for economic solution matters. The internet technology and its sophistication today really assists human beings to meet their needs. The inventors, innovators and entrepreneurs then begin to pick them as a transaction channel to satisfy human needs. This situation triggers the emergence of e-commerce or electronic commerce, a modern tool for online shopping and business transactions. E-commerce increasingly enables people in making transactions since it no longer requires people to provide much energy and time to find the things they need. It is in line with the essence of e-commerce, which is to let the buying and selling process not to be restricted by time and distance.

E-commerce in Indonesia is growing fast lately. If in the early 2000s, trade with physical stores or off-line stores - as seen in the mushrooming shopping malls in many places - found a very rapid growth momentum in Indonesia. The next ten years a dinamic gradual shifting took place. Facilitated with improved logistical 
access, some consumers (initially in big cities but now reaching smaller cities), are gradually turning to online purchases through e-commerce transactions. Online services gradually become a new darling for busy people who are eager to save time and travel costs. In conventional transactions people may take a lot of time and costs to reach the physical store; but with the presence of e-commerce, consumers can visit online stores with just a few clicks.

With the asssistance of e-commerce, searching for product items is much faster. People can use the search box to narrow down the kinds of products and search for a variety of products based on available categories. Another advantage is that online stores are open all the time for 24 hours within 7 days a week. Thus, it makes people able to search for various needs at any time. If it is previously difficult for people to find a physical store that is open at night or in the very early morning, a different situation is found in e-commerce. The vast number of products offered in e-commerce sites enables customers to compare shopping and get the best price. Online shopping through e-commerce also even frequently offers lower prices due to the discounts given.

The Indonesian government is now seriously exploring in depth and comprehensively the proposed tax imposition for e-commerce. The current discussion and consultation by the Indonesian government with ecommerce busines players in the preparation of appropriate tax regulations for e-commerce reminds us of the similar thing that was ongoing in the United States during the late 1990-s and the early 2000-s. In the midst of the public debate and the eagerness of the state government to tax e-commerce, the federal and legislative governments agreed to issue the Internet Tax Freedom Act (ITFA), which aims to provide sufficient time for discussion in the regulation of e-commerce taxation. Careful considerations and consultations between the federal government and the legislatives with their stakeholders in the US to discuss appropriate policy associated with commerce taxation were encouraged. With the ITFA, the consultations and discussions on e-commerce taxation was hoped to meet final conclusions in three years, namely in 2001 (Bick, 2000). Nevertheless, although several states have firmly decided to tax online purchasing, unsurprisingly, the issue of e-commerce taxation in the US continues to date. The culprit is due too many issues to be resolved involving many conflicting stakeholders in line with the very fast development of internet technology.

The rapid growth of e-commerce in Indonesia has resulted in a reduced share of the traditional market. It is indicated by the closure of several retail outlets in Indonesia, especially in Jakarta. Online transactions throughout Indonesia are now estimated to take $1 \%$ of total national retail spending. The figures in urban areas are certainly higher, even in the capital city Jakarta, it is estimated to have reached $20 \%$ of total retail spending in Jakarta.

The shifting condition has made the government conventional method to collect taxes from business and trade sectors to become partially obsolete. The ability of government to generate tax revenue in the conventional way is then no longer effective, given the market dynamics which partly shift from physical stores to the web store. Reflecting on the experience of other countries such as the US and New Zealand as reviewed in among others Hubbard (2003) in Ward \& Sipior (2004), Cline \& Neubig (1999), Goolsbee (2001), Omar, Kwun, \& Bhutta (2012), and Agrawal \& Fox (2015), Indonesian government will potentially also experience tax revenue loss due to the increasing number of online transactions that are untaxed or not detected by tax. The number is getting bigger along with the time and the development of internet technology especially, and information and communication technology in general.

This paper will discuss the following issues: the first, should Indonesian government imposes the tax on ecommerce; the second, how much is the potential tax revenue from e-commerce; and the third, how Indonesian fiscal policy perspective views e-commerce taxation. This study will not discuss more technical and detailed issues such as how to collect e-commerce tax and how much the appropriate e-commerce tax rate should be.

\section{Literature Review}

With reference to European Parliament (2012), e-commerce might be defined as commercial activities performed over new technology platforms via electronic or digital way. This new form of business 
encompasses diverse activities, from the electronic trading of goods, services, and ebanking, via on-line delivery of digital content, collaborative design and engineering, public procurement, to direct consumer marketing. Therefore, electronic commerce has represented a revolution benefiting informatics, computers and networks which enables new activities (e.g. virtual malls), and new provisions of traditional activities such as healthcare and education as well.

Furthermore, European Parliament (2012) explains that the categories of e-commerce might be classified along two dimensions, i.e. the nature of the item traded and the character of the agents involved. With respect to the nature of the item traded, the standard definition is separated into two main categories: distance selling and digital content services or direct electronic commerce. Distance selling refers to the electronic selling of tangible goods, which still must be physically delivered using traditional channels (i.e. postal services). Meanwhile, digital content services or direct electronic commerce, concerns the on-line ordering, payment and delivery of intangible goods.

European Parliament (2012) further clarifies that in regard to the character of the agents involved, the classical distinction is between sales from B2B (Business-to-Business) and B2C (Business-to-Consumer). $\mathrm{B} 2 \mathrm{~B}$ refers to the commerce between companies covering all transactions within the supply chain, except the final sale to the end consumer, while B2C generally refers to businesses selling to the general public for their private use via any electronic platform or internet. E-commerce is not just limited to the Internet. New technologies provide people with applications such as narrowband, broadcast, off-line devices, and networks which enable people to transact new electronic businesses. Nevertheless, the internet still serves the main tool to operate through, and it generates many innovative hybrid forms of electronic commerce.

In observing e-commerce including internet retail and its taxation, we can not be ignorant or remain uninformed about the situation in the US, a country where the kind of trade originates. Internet retail amounts to well more than hundreds billion dollars annually in the United States and accounts for an inreased share of the whole retail commerce. The most of Internet transactions takes place across state lines, with striking tax consequences. Conservative guesses about purchasing elasticities find that taxes may serve a significant contribution in shaping the geography and dynamics of online retail trade. Currently, the taxation policy on internet commerce has generated considerable attention. Sales and use taxes account for more than 30 percent of state tax revenues (Einav, et al., 2014). Foregone taxes on Internet sales could amount to $\$ 10$ billion a year, and this number is possible to rise (Maguire (2013) in Einav, et al. (2014)).

\section{Research Methodology}

This study is a descriptive analytical research. The research method is carried out by conducting a literature review on relevant journals and articles related to the economics theory on taxation and the empirical evidence on e-commerce taxation in Indonesia and other countries. In that regard, this study seeks to comprehend consumer behaviors in digital economy era, including its impact on taxation revenue or loss in a few countries, especially Indonesia.

The simple computation and assumption is adopted to find out potential revenue or loss estimates in 2017 and 2018. Valid Indonesian e-commerce data and regulation is obtained from We are Social \& Hootsuite Digital Report 2018, the Ministry of Finance and Bank Indonesia.

\section{Findings}

\section{E-Commerce in Indonesia}

E-commerce sector has become the new phenomenon in Indonesia's economy. In less than five years this sector has grown very fast, absorbing more investment inflows, creating new jobs and contributing to the country's economic growth. It is expected that Indonesia acquires between US $\$ 2$ billion and $\$ 3$ billion in digital economic investments per year. The figure takes 15 to 20 percent of foreign direct investment in the country (The Jakarta Post, 2017).

E-commerce has big potential growth in Indonesia. Based on BPS and We are Social \& Hootsuite's Digital in 2018 Report data, in 2018 there are 130 million of 265 million Indonesians which are active internet and 
social media users. The number of mobile phone owners reaches 178 million people with 120 million of them become active mobile social media users. This figure shows a rapid increase compared to the previous year. Active social media users in the internet increases by $23 \%$ in 2018 , while active social media users via mobile phones increases by $30 \%$. In terms of the number of internet platform users, in 2018 Indonesia ranks the fourth in the world for the most Facebook users, under India, US and Brazil; and ranks the third in the world for the most Instagram users. In terms of the most social media users on mobile phones, Indonesia also records the world's big three after China and India.

Out of 265 million Indonesian people, more than 28 million people buy products online either through a computer or smartphone. The growth potential of this number is very large considering that the current number is less than $10 \%$ of the Indonesian population, and e-commerce consumer growth potential can reach $13 \%$ per year referring to the 2017 growth. Smartphone capability that has increased sharply in internet connection capabilities has also contributed to the increasing number of online buyers in Indonesia. The available data in 2017records that every e-commerce consumer in Indonesia buys products through ecommerce amounting to US $\$ 251$ in average (approx. Rp. 3.7 million, US $\$ 1=R p 13,400$ ).

\section{Should Indonesian Government Tax E- Commerce?}

To tax or not to tax e-commerce has been a big fiscal policy issue for many countries before the tax policy for e-commerce is decided. The current collection problem in e-commerce facing Indonesian government is somewhat similar in the US since 1998 to date. In 1998, the US Congress passed the 1998 Internet Tax Freedom Act which restricts new internet-related taxes. The moratorium states that there should be no new taxes on internet access, and there should be no multiple or discriminatory taxes on e-commerce (Simkin, Bartlett, \& Shim, 2002).

US is the first home for internet but the public controversy of taxing or not taxing e-commerce still takes place. A 1992 US Supreme Court ruling established the precedent for exempting online retailers from sales taxes, on the other hand, various states have issued "Amazon laws" which treat online sales in a similar way that brick-and-mortar sales are taxed. Just in the midst of 2018 the US Supreme Court has supported taxing the online retailers located in different states. Like Indonesia, internet and e-commerce stakeholders (businesspeople, politicians, academics) in US are split into two advocates, pro taxation and against taxation. Two sides advocate a contrary standpoint: the advocates of tax free internet and e-commerce, and the advocates of internet and e-commerce taxation. The two sides often mix up the broader issue of the taxation of access to the internet with the issue of the taxation of ecommerce.

Ward \& Sipior (2004) mentions that advocates of a tax-free internet argue that charging internet access taxes and fees will burden the society with higher cost for the consumer and thus limiting the growth of internet use and e-commerce. Further, these advocates argue against imposing e-commerce business to collect and remit transactional taxes on remote e-commerce merchants due to significantly additional cost of compliance reason - while social media platforms which are also used for sales and transactions are free from such obligations. Such cost of compliance is perceived as a barrier to market entry for small, start up e-businesses. Such a cost is also perceived as a big burden for existing online local marketplace players in Indonesia, which makes them refusing the Indonesian government idea to accept the role of collecting and remitting taxes on remote e-commerce vendors. They view that the duty of tax collection and remittance should be the role of tax authorities, not theirs. Assuming the role will impede them to continue running the business, since their e-commerce vendors will go away and settle back in previous social media platforms such as Facebook and Instagram which is not required to collect taxes on posted e-commerce sales from merchants and sellers.

If it is taxed, the question is whether this policy will not just discourage and shut down the Indonesian newly growing e-commerce industry. If that happens, it means the Indonesian tax policy fails to carry out its function to regulate the economy. Many micro, small and medium-sized businesses just start selling their products online, feeling happy not having to be burdened with expensive operating costs and shop rent. Mostly the local e-commerce start ups in Indonesia can be labeled 'infant industry', which must compete with foreign mature, competitive, large, and established e-commerce industries like Amazon, AliBaba, eBay, and Paypal which have entered the Indonesian domestic market. 
Yet, not taxing e-commerce industry due to it is an infant industry is not strong reason, since too often, infant industry protection turns into established industry protection (Goolsbee \& Zittrain, 1999). The time lag that government needs to comprehend the e-commerce business and prepare the suitable and necessary tax regulation will provide enough grace period to be mentally and financially prepared. Meanwhile, from regulatory perspective, Indonesian tax regulation has provided space for a company (in every sector) to credit its losses to its tax liabilities up to five-year period in case of an e-commerce company records losses.

Meanwhile, the opposing side - the pro taxation is clearly explained by Ward \& Sipior (2004). The study states that the advocates of internet taxation emphasize on the loss of tax revenue and tax neutrality regardless of the business model, whether it is conventional offline or current online model (see publications among others Hubbard (2003) in Ward \& Sipior (2004), Cline \& Neubig (1999), Goolsbee (2001), Omar, Kwun, \& Bhutta (2012), and Agrawal \& Fox (2015)). Non-compliance with the payment of transactional taxes has real revenue impact for government. Beside US, New Zealand is another country aware that it is losing significant revenue due to e-commerce (Agrawal \& Fox, 2015).

The concerns over the loss of tax revenue are not without basis as it is supported by several studies and data. We can refer several papers published discussing the issue. The relationship between e-commerce taxation and fiscal impact can be learnt from Goolsbee (p. 16) and McLure papers. In Goolsbee (2001), tax revenue loss from not taxing e-commerce was estimated small in 1999 , only $0.3 \%$ of total sales tax revenue of US $\$ 203$ billion. In five years, the figure would be bigger but still modest in $2.6 \%$ of projected 2004 sales tax revenue. In more than fifteen years (2015 or later), if e-commerce is not taxed, the total revenue loss arising from e-commerce achieves $10 \%$ of projected sales tax revenue. More recent research by Omar, Kwun, \& Bhutta (2012) shows the data of tax revenue losses incurred by US government by not taxing online purchases in 2007 is US $\$ 48.2$ billion. The study then makes projection revenue losses in 2011 which figure keeps higher and reaches US $\$ 62.1$ billion.

Another evidence is from the California State Board of Equalization, which estimates that in 2001 uncollected taxes from mail order and e-commerce sales cost the state and local governments US $\$ 1.2$ billion (Hubbard, 2003 in Ward \& Sipior, 2004). Transactional taxes are a substantial source of revenue, thus an increase in the non-compliance of tax payment could result in an increase in other taxes or a decrease in government functions. Moreover, an increased ability to avoid or evade transactional taxes could give adverse affect to the local tax base. Other supporting data is shown by Cline \& Neubig (1999) for US market that in 1998 approximately $\$ 2.6$ billion (13\%) ecommerce retail sales had potential sales and use tax collection issues and there were sales and use tax erosion of less than $\$ 170$ million in 1998. The latter figure was one-tenth of one percent of total sales and taxes collected by all US state and local governments.

In Indonesian case, based on $\mathrm{BI}$ prediction the country itself has potential sales and consumption tax collection issues toward Rp 102,6 triliun e-commerce retail sales in 2018 (Kementerian Keuangan, 2018). The figure is slightly bigger if we use the data compiled in We are Social \& Hootsuite's Digital in 2018 Report. Despite the issued tax collection regulation for the e-commerce industry under DG of Taxation Regulation No. SE-62/PJ/2013, we remain skeptical that this regulation is effective due to incomplete comprehension of the tax authorities and government to the e-commerce business model.

Despite the Indonesian newly developing e-commerce industry, a fraction of the offline retailers' segments and market share have partially shifted and purchased online. Several marketing experts have reviewed the phenomenon of the less visiting consumers in shopping malls to buy consumer goods due to the trend of consumers shifting from purchasing offline in physical stores to online retailers. This phenomenon is so obvious in megacities like Jakarta, where the movement pattern of shopping consumers from malls to online retailers may reach $20 \%$ of the total value of retail sales in Jakarta. This figure is much far above the national level, which is only $1 \%$ of the total value of retail sales in Indonesia. When many consumer goods stores in the mall and Mall Matahari shopping outlets are closed, the suspicions go to online stores as one of the prime causes. It gets natural then that the anxiety of the offline retailer's industry arises that e-commerce industry will take over the market from offline retailers, which have invested a lot in physical store infrastructure and been compliant in paying taxes. 
The absence of taxes on online businesses, especially foreign players, will be contrary to the principle of equality and neutrality in the imposition of tax, because there are some players with similar situations (both selling products to customers and gaining profits) who are being discriminated, while other players are given a privilege in the imposition of tax. By not taxing e-commerce businesses, especially for foreign players, this situation will potentially hold Main Street merchant's hostage in order to gain lower taxes. The argument is that if e-commerce or all remote commerce is not taxed, representatives of Main Street will pressure the government to reduce taxes, so that they will not be at so great a competitive disadvantage (McLure, 2002). Besides - from macro perspective - effectively exempting remote purchases from sales taxes is an indirect and unevenly focused means of promoting the internet's growth. And that is unlikely to bring significant benefits in terms of additional users or uses (Woodward (2001) in McLure (2002)).

\section{The Complexity of E-Commerce Taxation}

The taxation of e-commerce is a complex issue which cuts across city, county and state borders within a country, national borders, and tax types. The growth of e-commerce raises complicated issues with regard to the taxation of multi-jurisdictional transactions and the sourcing of sales of, or income from, services or intangible property transactions. Several trends are identified contributing to the complexity of e-commerce taxation, including borderless commerce, digital convergence, virtual organizations, automated transactions, and new business models (Ward \& Sipior, 2004).

The above complexity is challenging permanent establishment principle, which has been the established consensus on the taxation of international business (Akcaoglu, 2002). In globalization era when multinational companies invest and operate here and there, the permanent establishment is a good concept and solution indeed to fix the problem of determining taxing jurisdiction among many countries, until the borderless internet era comes. Permanent establishment has been the request of Indonesian government to all multinational companies that intend to sell their products, either in goods or services in Indonesia. We remember that the long tax dispute between Indonesian government and Google for Google tax liabilities in 2015 was sourced in the non-existence problem of Google permanent establishment in Indonesia. The problem has made the action of levying the Google business profit from its operation in Indonesia troublesome in the view of Indonesian tax authorities. The application of permanent establishment for taxing e-commerce companies' business profit is still a major concern for many governments, especially for those governments whose countries are unfortunately not selected by a major e-commerce company as the permanent establishment location. Taxing e-commerce business profit needs another concept and consensus other than permanent establishment to complement the tax gap that is difficult to capture nowadays.

In welcoming this new era - internet and e-commerce era - Indonesian government can not depend only the permanent establishment to collect sales taxes. People are now in the information age where borders are not very important, and intangibles and services are a larger part of the GDP than they were years ago. Major international e-commerce companies may locate their web servers in any country but selling their products in Indonesia without establishing their permanent establishment in Indonesia (Akcaoglu, 2002). As illustration, although gaining much profits from Indonesian consumers, Google established the regional office in Singapore, and set up only a representative office in Indonesia - which is not a permanent establishment. Representative office does not commit sales, but only market their products. Although the transaction and income are generated in Indonesia, those transaction and income recognition is conducted by Google regional office (Google Inc's Asia Pacific headquarters) in Singapore.

\section{Potential Tax Revenue}

We use two data sources: (i) We are Social \& Hootsuite's Digital data in 2018 Report and (ii) Bank Indonesia estimation results to calculate the potential tax revenue of Indonesian e-commerce sector. By using the survey-based data in the first source, it is known that the number of online buyers in Indonesia through mobile phone and internet devices reached 28.07 million people in 2017. Available data records in average every e-commerce consumer in Indonesia spent US \$ 251 (or approx. Rp3.7 million) to buy products through e- 
commerce throughout the year 2017. The total purchase of Indonesian e-commerce consumers recorded in 2017 reached US $\$ 10.269$ billion (or approx. Rp137.6 trillion, US $\$ 1=\mathrm{Rp} 13,400$ ).

If only Value Added Tax is collected with $10 \%$ current tax rate, the potential revenue for the state budget can be as much as US\$1.03 billion or Rp13.76 trillion in 2017. Assuming this value increases by $10 \%$ per year, the potential revenue from Value Added Tax reaches around Rp15.14 trillion in 2018. To estimate the potential income tax requires some assumptions. Based on Glenn Luk estimate - he is an experienced, fifteen years long investor at Luke Capital Reading - profit margins from marketplace and online retailers such as Amazon and Alibaba are around 4\%, so it is assumed that profit margins from all online retailers in Indonesia like Lazada, Bukalapak, Gojek, Tokopedia, Shopee, etc. are more or less similar. The calculation of potential net income value generated by all the online retailers in Indonesia in 2017 is $4 \% \times$ Rp137.6 trillion equals to Rp. 5.5 trillion. By multiplying this number with $25 \%$ current corporate tax rate, the potential income tax in 2017 is IDR 1.38 trillion and in 2018 (assumed to increase by 10\%) to almost IDR 1.5 trillion. By summing up the potential revenue from both types of taxes (i.e. VAT and Income Tax), the value of potential tax in 2017 is almost around IDR 15.14 trillion and by 2018 around Rp 16.64 trillion, with the value of potential VAT accounts for around $90 \%$ of the total potential tax revenue from Indonesian e-commerce sector.

By using Bank Indonesia estimation that in 2017 there was Rp102.6 trillion in Indonesian retail e-commerce sales, the calculated potential VAT with similar current $10 \%$ rate is Rp10.26 trillion (2017) and Rp11.3 trillion (2018), assuming $10 \%$ increase. The calculated potential income tax with similar current corporate tax rate then is Rp. 0.4 trillion (2017) and Rp. 0.45 trillion (2018), as the result of $4 \%$ multiplied by Rp102.6 trillion. In total, the potential tax from both types of taxes (VAT and Income Tax) is Rp10.66 trillion (2017) and Rp 11.75 trillion (2018).

Those potential tax revenues will become partial or the most of government tax revenue loss if it remains untaxed or ineffectively taxed. The longer it is untaxed or ineffectively taxed, the bigger the revenue loss that the government incurs, which means the losses for public too. The losses could be in the form of, among others, a particular number of school and hospital buildings, bridges, and roads which can not be built, and some particular public service which can not be upgraded in terms of quality. The potential revenue from ecommerce should not be neglected since it will be meaningful to help achieve Indonesian development goals.

\section{Taxing E-Commerce and Fiscal Perspective}

The emergence of e-commerce can be viewed as presenting an opportunity to modify Indonesian existing tax systems to address today's business model. Much work is needed so that tax systems can apply to ecommerce and satisfy the principles of good tax policy. This is not a small task, but one that should be pursued in a collaborative fashion by businesses and governments. There is a need to consider the global nature of e-commerce to tackle international tax reform issues in a collaborative work among countries (i.e. in G20, OECD and APEC forums) as well (Nellen, 2001).

Import control policies are important since Indonesia has experienced current account deficits and trade deficits for a couple of times. Tax policy can be used for the purpose of regulating the economy and reducing the current account deficit. If the purchase of online imports originating from Amazon and Alibaba's foreign marketplace has been excessive, the imposition of sales tax in an appropriate rate on such online purchases will be able to restrict online imports which someday may contribute substantially to current account deficit.

If government allows e-commerce remain untaxed at this point of time, the impact of imports from online purchases on tax revenue losses will be substantial in the long run. According to the prediction in Goolsbee (2001) for US case study, it will happen in 15 years from 1999. In accordance with the principle of neutrality, the imposition of tax on e-commerce (by VAT and import income tax) on online purchasing from foreign online retailers will probably prevent - for particular products - the massive shifting of local consumers from domestic offline and online retailers to foreign online retailers. In that case, it will reduce the need for USD and save Indonesian foreign reserve. Taxing e-commerce should also be applied to all e-commerce platforms, including social media platforms that are used for marketplace for e-commerce transactions, such as Facebook and Instagram. Thus, the specifically built platform for marketplace that is now growing will not 
be harmed due to consumers shifting back to the previous e-commerce model that uses social media platforms and has no specific marketplace.

The imposition of tax on e-commerce should take the principles of equity and fairness into consideration. The tax rate among business players does not have to be the same, but the rate should be adjusted to the ability of taxpayers. Therefore, the tax rate does not have to be the same (1) between online and offline merchants; (2) among online platforms with different level of turnover; (3) between big vendors and micro small medium size enterprise merchants who use the marketplace platform.

The fiscal policy implementation to impose taxes on e-commerce should not be strictly enforced in the beginning, yet socialization and educative campaigns are emphasized more, including a campaign to invite merchants to register as taxpayers. The gradual implementation campaign will possibly not have a significant impact on Indonesian fiscal conditions considering the losses of tax revenue are possibly small in the short run (Goolsbee, 2001). The condition of non-aggressive taxation implementation is also intended to help the online platform in preparing compliance tools that will potentially leave a high initial cost of compliance in the beginning.

For online merchants, there should be differences of tax treatment in income tax for the vendors under a particular threshold. Vendors under micro small medium sized enterprises group may need to get smaller tax rate and may not be taxed if their value of sales is below a threshold. Whereas the imposition of VAT will apply to all transactions without considering the vendors' threshold income, and whether it is a local or international vendor. Especially for international vendors, under current tax system, they should be liable to another type of taxes i.e. import income tax.

Referring to Goolsbee (2001), the implementation of e-commerce taxation that is not too aggressive in the initial stages will prevent the impact of negative externalities and the slower spread of the internet. As time goes by, when the internet has become an established retail channel, equal treatment may start to apply for all online platforms and online vendors. The hope is that of course the results will be desirable outcome and credible compromise among stakeholders.

\section{Conclusion}

This study seeks first to answer the question whether Indonesia should tax its e-commerce or not. Taking into considerations from all perspectives associated with to tax or not to tax e-commerce discussed above, the result of analysis favors Indonesia to tax e-commerce. The remaining question lies on when, how much and how to tax it. The complexity of e-commerce taxation has left the permanent establishement consensus in international taxation ineffective.

The total potential tax revenue on e-commerce from VAT and income tax in 2018 ranges from almost Rp11,75 trillion to Rp16,64 trillion, with VAT dominates the contribution up to more than $90 \%$ of the total tax revenue. By not levying the tax in the year means Indonesian government will lose a partial or the most of tax revenue. The revenue loss is potentially getting bigger in the coming years if the government still fails to collect the tax.

Tax imposition should adhere to the principles of equity, fairness, and neutrality. To be effective, taxation should also apply to all e-commerce platforms and all vendors. The tax rate does not have to be the same, but is adjusted to the ability to pay taxes. E-commerce taxation should not be strictly enforced in the beginning, yet more is emphasized on socialization and education actions. It is also intended to help the online platform to be compliant.

Based on previous studies, if Indonesian government does not tax e-commerce now, it would be fine since the tax revenue loss is still small in the beginning of Indonesian e-commerce industry. In the near future (say five years), the percentage or the slice of tax revenue loss becomes bigger but still modest. However, in the long run if Indonesian government does not formulate the right fiscal policy to tax e-commerce, the tax revenue loss will get even bigger and be substantial. In terms of how much the losses are, Indonesian government should encourage studies in the near future to capture valid and detailed current and projected data of Indonesian e-commerce real and potential tax revenue. 
Tax policy can be used for the purpose of regulating the economy, such as to tame Indonesian classical problem in balance of payment, originating from current account deficit and trade deficit. Let's say once the purchase of online imports originating from foreign marketplace has been excessive, the imposition of an appropriate tax rate on online purchases will be able to control online imports.

\section{References}

Agrawal, D. R. \& Fox, W. F. (2015). Sales Tax in an E-commerce Generation.

Akcaoglu, E. (2002). International Taxation of Electronic Commerce: A Focus on the Permanent Establishment.

Bick, J. (2000). Implementing E-commerce Tax Policy. Harvard Journal of Law \& Technology, Vol. 13 (3), 2000.

Cline, R. J. \& Neubig, T.S. (1999). The Sky Is Not Falling: Why State and Local Revenues Were Not Significantly Impacted by the Internet in 1998.

Einav, L., Knoepfle, D., Levin, J., \& Sundaresan, N. (2014). Sales Taxes and Internet Commerce. American Economic Review 2014, 104(1): 1-26. http://dx.doi.org/10.1257/aer.104.1.1

European Parliament (2012). Simplifying and Modernising VAT in the Digital Single Market. Written by Naess-Schmidt, Ali, \& Arias.

Goolsbee, A. (2001). The Implications of Electronic Commerce for Fiscal Policy (and Vice Versa). Journal of Economic Perspectives - Vol. 15, No.1. Pages 13-23. DOI: 10.1257/jep.15.1.13

Goolsbee, A. \& Zittrain, J. (1999). Evaluating the Costs and Benefits of Taxing Internet Commerce. National Tax Journal 52(September): 413-428. http://nrs.harvard.edu/urn-3:HUL.InstRepos:9696321

Hubbard, C. (2003). California officials consider proposals to tax online sales. State Tax Review, Vol. 64, Issue 9, pp. 3-5, March 4, 2003.

Kementerian Keuangan (2018). Media Keuangan Vol. XIII/126, Maret 2018

McLure, C. E. (2002). Thinking Straight about the Taxation of Electronic Commerce: Tax Principles, Compliance Problems, and Nexus

Nellen, A. (2001). E-Commerce: To Tax or Not to Tax? That Is the Question ... Or Is It? Computer and Technology Law Conference: Software, Networks and E-Commerce. Berkeley Center for Law \& Technology and The University of Texas School of Law

Omar, A., Kwun, O., \& Bhutta, M. K. (2012). The Impact of e-Commerce Tax Policy on State and Local Government Revenue.

Simkin, M. G., Bartlett, G. W., \& Shim, J.P. (2002). Pros and Cons of e-Commerce Taxation. International Business \& Economics Research Journal, Vol 1 (2).

The Jakarta Post (2017). Unleashing the power of e-commerce for Indonesia. Written by Fajrin Rasyid. Fri, August 4, 2017

Ward, B. T., \& Sipior, J. C. (2004). To Tax or Not to Tax E-commerce: A United States Perspective. Journal of Electronic Commerce Research, Vol. 5, No.3, 2004

We are Social \& Hootsuite (2018). "We are Social \& Hootsuite's Digital in 2018 Report"

Woodward, G. T. (2001). Economic Analysis of Taxing Internet and Other Remote Sales. Testimony before the Committee on Finance, U.S. Senate, August 1. 